
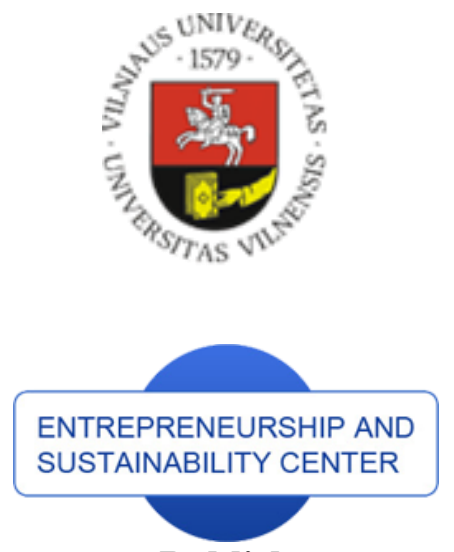

Publisher

http://jssidoi.org/esc/home

\title{
PERFORMANCE MEASUREMENT ISSUES IN CENTRAL BANKS
}

\author{
Deimantė Teresienè \\ Vilnius University, Sauletekio av.9, Vilnius, Lithuania \\ E-mail:_deimante.teresiene@ef.vu.lt
}

Received 20 March 2018; accepted 6 May 2018; published 30 September

\begin{abstract}
Central banks play an important role in financial system and are an essential part of overall public sector finances. Monetary policy responsibilities are common to all central banks. Financial stability is another area of central bank activity. Central banks provide financial stability by controlling the actions of the commercial banks. Central banks also are as lenders of last resort and payment mechanism managers. But the key issue in this article is to concentrate on foreign reserves management as a source of bank profit. The aim of this research is to create a performance valuation framework which could help to compare foreign reserves management results in different central banks. Quantitative and qualitative reasearch methods are used in this article. For quantitative analysis various statistical techniques are used and for qualitative analysis the main method is a case study. There are a lot of measures for commercial banks sector valuation but in practice we see a lack of analysis tools for central banks performance measurement. Foreign reserves management is an on-going process aimed at maximizing expected return over a defined investment horizon. Valuing foreign reserves management results we should concentrate on specified risk budget and the opportunity to have different kind of assets in the investment portfolio.
\end{abstract}

Keywords: central banks; foreign reserves; performance measurement

Reference to this paper should be made as follows: Teresiené, D. 2018. Performance measurement issues in central banks, Entrepreneurship and Sustainability Issues 6(1): 176-189. http://doi.org/10.9770/jesi.2018.6.1(12)

JEL Classifications: E58, G2

\section{Introduction}

Despite the fact that central banks control a substantial sum of wealth there is little published about the asset allocation process for foreign reserves management. The majority of public research has been focused on optimal level of foreign reserves but not to the issues how these reserves are managed. From theoretical point of view central banks are not profit seekers but in practice the situation is quite different. The finances of central banks have not yet attracted scientists' attention. But it makes sense to analyse central banks' results as they are a source 
of government income and central banks' gains and losses belong to society. In most cases, governments are the main shareholders to whom central banks distribute their profits.

Some central banks have private shareholders which usually receive predefined dividends which can be limited in law. In the literature we can find that most central banks which were created before 1935 had private owners. The nationalization process started in 1935 and the first nationalized central bank was in New Zealand. Later central bank in Denmark (1936) and Bank of England (1946) were nationalized. Nowadays there are some central banks which have private ownership. The latter central banks are in Belgium, Greece, Italy, Japan, South Africa, Switzerland, Turkey and the Federal Reserve.

According to Bank of International Settlement financial results may be important for central bank despite it can create money to pay its bills because losses or negative capital can raise doubts about central bank's ability to deliver on policy targets. Having losses central banks can face poltical pressure. So it could be the reason why central banks use net income to build reserves against future losses. Sometimes a part of built reserves central banks transfer to the Government even if they have a loss for accounting period.

Igor Goncharov, Vasso Ioannidou and Martin Schmalz in their article "(Why) do central banks care about their profits" (2017) presented the results that central banks are significantly more likely to report positive profits than slightly negative profits despite the fact that they are not profit seekers. Those mentioned authors described also political and public pressure in the cases when central bank discontinues profit distribution to the government. Of course in such kind of situations central banks are when they have a loss. So, according to these findings, and also valuing practical issues, and including the fact that central banks seek financial independence the conclusion can be made that profitability principle in foreign reserves management framework is not the last principle that central banks care about. Knowing the main investment portfolio principles there can be rised a debate that nowadays we have non-traditional central banking.

Daniela Bunea, Polychronis Karakitsos and others in ECB occasional paper series artice "Profit distribution and loss coverage rules for central banks" (2016) wrote that the main driver for central banks performance management is the extent to which policy objectives: controlling inflation or achieving financial stability were achieved. According to the authors, profit maximization is not, and must not be, a goal for central banks. But this idea can not be taken without any conditions. If central bank is granted financial and institutional independence then it should include profit seeking in its strategic aims. According to ECB paper, there can be different approaches of profit disstribution to government:

1. a fixed percentage of the current net profit is distributed;

2. a fixed percentage of the current net profit is allocated to reserves without any reference to a limit for these reserves;

3. an amount between zero and a maximum percentage of the current net profit is allocated to reserves;

4. a (usually fixed) percentage of the current net profit is allocated to reserves until these reach a certain target level which is usually a proportion of a particular balance sheet item;

5. no value or percentage is defined in the legal framework in relation to distribution.

The aim of this article is to create a performance valuation model which could help to compare different central bank financial results from the point of foreign reserves management return. In order to achieve the main goal of 
this research some objectives were set. The first objective is critically to assess the impact of foreign reserves management governance to investment results. The second objective is to identify the connection between the size of foreign reserves portfolio, risk budget, limit system and central bank's performance results. And finally, the last objective is to evaluate the influence of tendencies in financial markets on central bank's profit.

In this research were analysed 191 institutions: central banks and monetary authorities. The main limitations were that central banks do not disclose enough information about foreign reserves management process and especially they do not want to disclose investment performance results. But it is not a good practice and centrtal banks should be more opened to society.

This article consists of some sections. Section 2 presents a review of the literature on foreign reserves management governance and the research of different central banks' results. Section 3 presents central banks' performance valuation framework and in section 4 there is presented a case study of Swiss National Bank performance results.

The methods used in this research are analysis of scientific literature, statistical data analysis, case studies.

\section{Foreign reserves management governance and investment results}

According to International Monetary Fund (IMF) "Revised guidelines for foreign exchange reserve management" (2013), reserve management is a process that ensures that adequate official public sector foreign assets are readily available to and controlled by the authorities for meeting a defined range of objectives for a country or union. These revised Guidelines are used by most central banks as a set of basic principles in formulating sound reserve management policies and practices. Revised Guidelines provide a more comprehensive coverage of risk than the 2001 Guidelines.

IMF in the 2013 Guidelines explains the main objectives of holding official foreign reserves. So every country needs foreign reserves for:

1. "support and maintain confidence in the policies for monetary and exchange rate management, including the capacity to intervence in support of the national or union currency;

2. limit external vulnerability by maintaining foreign currency liquidity to absorb shocks during times of crisis or when access to borrowing is curtailed, and, in doing so;

3. provide a level of confidence to markets that a country can meet its current and future external obligations;

4. demonstrate the backing of domestic currency by external assets; assist the government in meeting its foreign exchange needs and external debt obligations;

5. maintain a reserve for national disasters or emergencies." (IMF "Revised Guidelines for Foreign Exchange Reserve Management").

The specific objectives of holding foreign exchange reserves can differ in various countries but the fact that reserves are held by central banks to guard against rainy days can be stated as general objective in all countries. 
The author John Nugee (2001) from the Bank of England in his paper "Foreign exchange reserves management" explained that there can be and specific obectives, as for example, reserves can be held as an investment fund, primarily for financial gain. The author stressed that before creating a framework for foreign reserves management and creating benchmarks the Board should be familiar with the foreign reserves holding objectives.

Foreign reserves usually are managed using three broad investment parameters, which are broadly known as main principles for reserve managemet. These principals are safety, liquidity and profitability. After analysing different central banks the results have shown that some central banks have diversification and reputational principles (cases of Czech Republic and Canada).

Foreign reserves managers have to take important decisions that influence their choices with respect to asset allocation, currency composition and asset classes, while ensuring that they meet the three main goals of capital preservation, liquidity and income generation.

After analysing different central banks' foreign reserves management policies the conclusion can be made that there is no one unique foreign reserves management framework. In some central banks there can be four levels of decision making processes and in others there are three or two levels. If there are four levels for foreign reserves management then there are long term investment decisions, strategic asset allocation, tactical asset allocation and at the lowest level there is investment portfolio management with internal or external management. Four level foreign reserves management framework is used in Swiss National Bank.

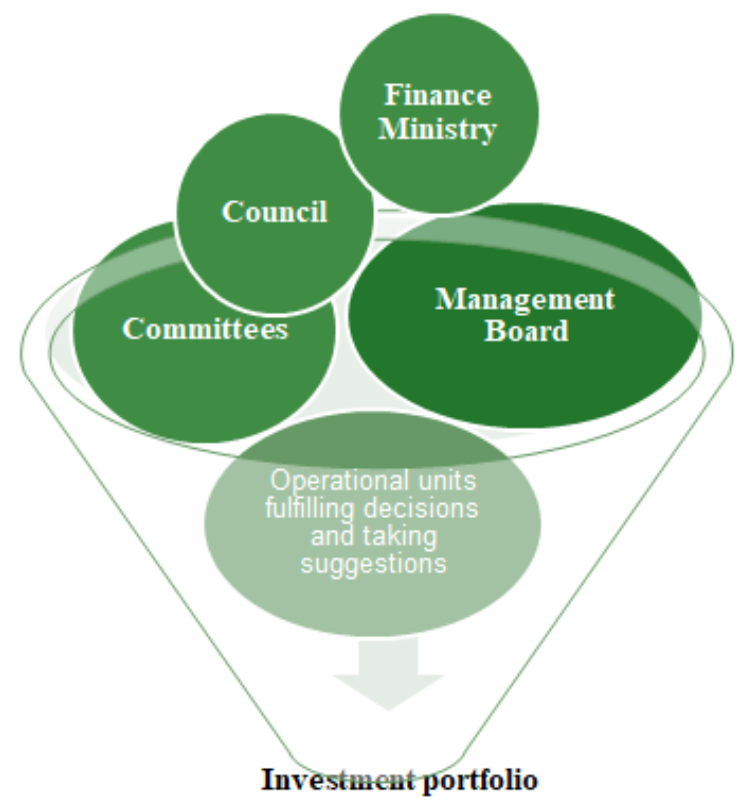

Fig.1. Levels of decision making

Source: Done by author

In figure 1 we can see different levels of foreign reserves management decisions. As the research showed in some countries Finance Ministry participates in decision taking process but it is not very common case. In some cases there can be Council and Management Board but the more common practice is that central bank has only Management Board. Usually central banks have different committees (Investment committee or Risk management committee), but the role of committees can also fulfill a group of responsinble operational units. 


\section{Performance measurement framework}

After analysing the main aspects of foreign reserves management governance and decision taking process it is important to analyse how decisions taking at the top level can influence foreign reserves management results.

Usually politicians and society like to compare different central banks or monetary authorities' financial results just looking at the final net profit. But this type of analysis could not be done as those institutions have different abilities for profit generation. As for example, if a Board in a central bank or monetary authority is very conservative and doesn't want to take more risk by allowing to include more risky asset into foreign reserves portfolio than in the economic growth cycle such central banks will generate less attractive financial results.

In figure 2 there are the results which were made in 1991 and announced by Brinson, Hood \& Beebower in the article "Determinants of Portfolio Performance" in Financial Analysts Journal. In 2018 the World Bank once again presented those findings as suitable drivers for nowadays long term investment success. The main driver of long term investment success is strategic asset allocation. Strategic decisions are taken at the top level. After analysing 191 different monetary policy institutions can be made a conclusion that usually these types of decisions are taken at the Board or Management level. Sometimes Finance Ministery can set some guidelines but they are usually very broad. Under the strategic asset allocation, the Management Board usually determines currencies and asset classes in which foreign exchange reserves can be invested. The Management Board also sets limits and risk tolerance for foreign reserves investments.

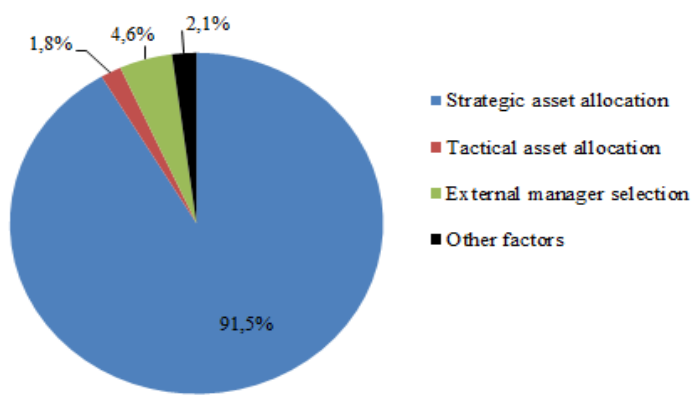

Fig.2. Key drivers of long-term investment success

Source: World Bank, Reserves Advisory and Management Program, Market Risk, Indexation of Treasury Securities and Performance Measurement, January 22-26, 2018 | Paris, France

Foreign reserves can be managed internal or external. Looking at the figure 2 we can see that external manager selection is another important factor for better foreign reserves management results. The main explanation for that could be diversification effect as external managers can have different views on financial markets or can use more sophisticated investment strategies. Tactical asset allocation is another factor which can add value to investment results and in other factors we can include practical portfolio managers' decisions, which are called "Alpha".

After analysing many central banks it can be said that strategic asset allocation decisions, taken at the Board level, had the biggest impact on financial results. The main point here is the structure of strategic benchmark. Portfolio size can create more opportunities for investment return but it is not the main factor. Some central banks, having huge foreign reserves can even generate loss if the bank is very conservative and does not want to take more risk in low or even negative yields environment. Without risky decisions conservative central bank also will not achieve good results in increasing yield cycle as values of bonds portfolios will decrease. 
Board decisions: risk budget-risk tolerance, asset classes, limits systems, governance framework.

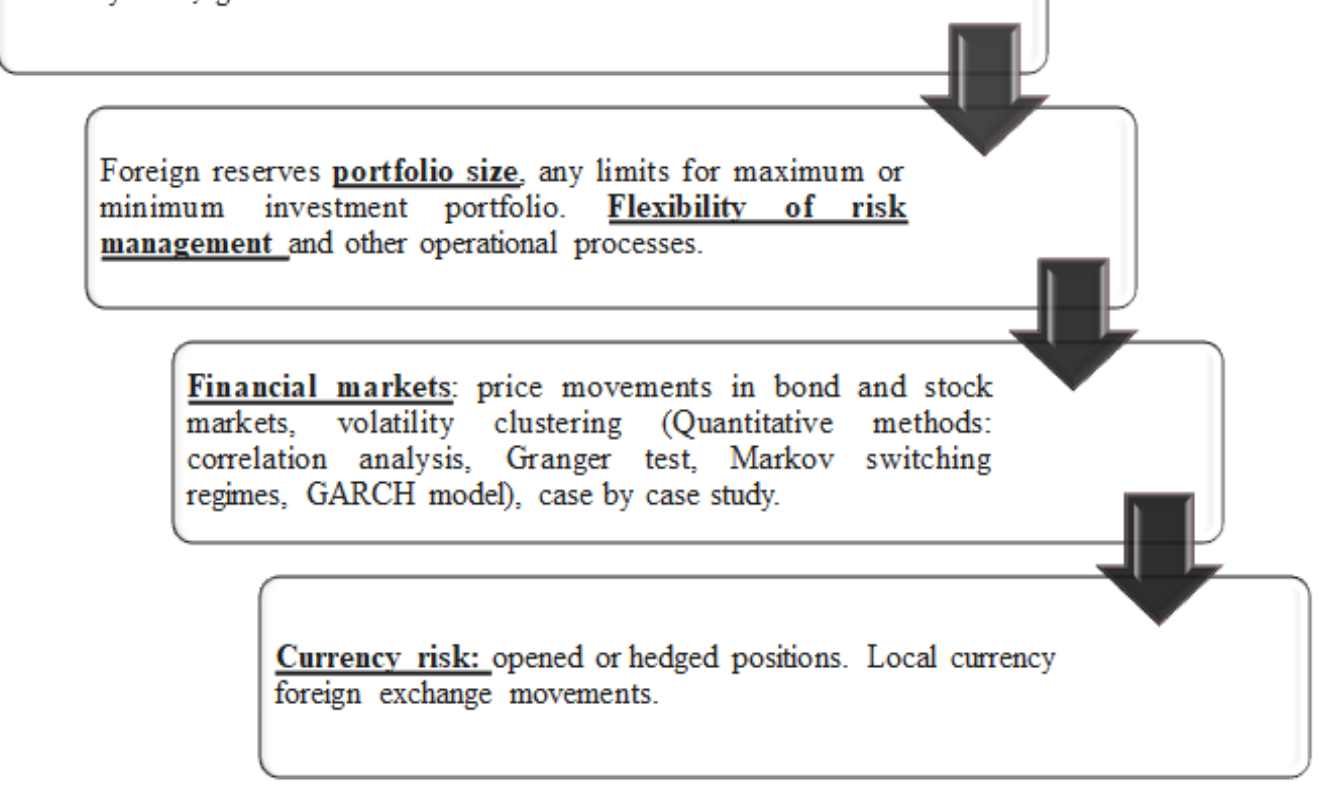

Fig.3. Central bank's performance measurement framework Source: Done by author

In figure 3 is shown the central bank performance measurement framework which can be used in comparing different central banks results. But the main idea of this framework is to pay attention to main factors which can influence foreign reserves management results. So once again can be mentioned that the main factor is going from the top level and then we should value tendencies in financial markets and finally currency risk exposure.

\section{Case study: Swiss National Bank}

For the case study analysis Swiss National Bank (SNB) was taken because this central bank achieved impressive profit in 2017. The Swiss central bank announced that expects a record 54 billion CHF profit in 2017.

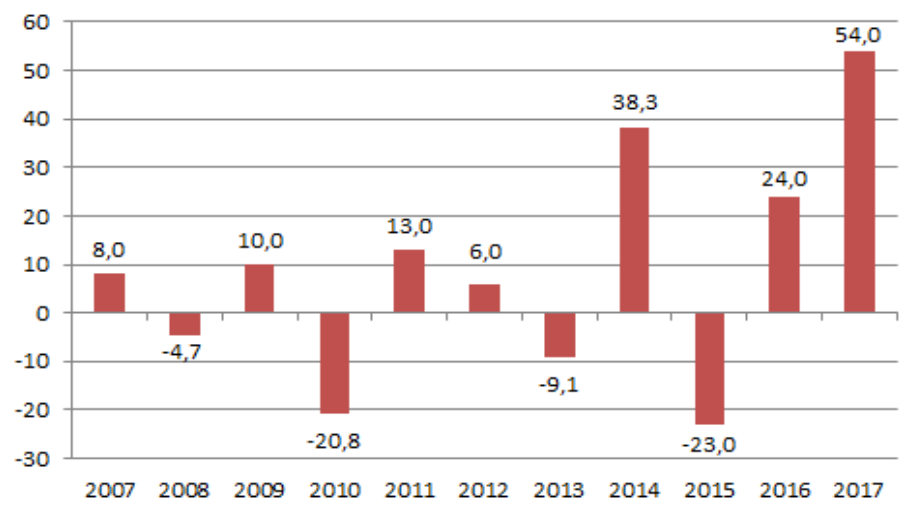

Fig. 4 SNB profit in billions $\mathrm{CHF}$ 
According to the central bank performance measurement framework, which was presented in section 3 the analysis of Swiss central banks results should be started from governance framework and Government Board decisions. Swiss National Bank has four level foreign reserves management framework. At the top level there is long term asset allocation with 5 year investment horizon. At this level responsibility is taken by the Governing Board, guideline - function of currency reserves and tasks: appropriate long-term risk/return profile or risk tolerance.

Table 1. Foreign reserves management levels

\begin{tabular}{|c|c|}
\hline Long-term asset allocation (LAA) 5y-Horizon & $\begin{array}{l}\text { - } \quad \text { Responsibility: Governing Board } \\
\text { - } \quad \text { Guideline: Function of currency reserves } \\
\text { - Tasks: Appropriate long-term risk/return profile (risk } \\
\text { tolerance) }\end{array}$ \\
\hline Portfolio management (Internal/External) & $\begin{array}{ll}\text { - } & \text { Responsibility: Portfolio managers } \\
\text { - } & \text { Guideline: Tactical benchmarks } \\
\text { - } & \text { Tasks: Implementation of TAA, generation of ,Alpha“ }\end{array}$ \\
\hline
\end{tabular}

Going from the top at the second level in central bank foreign reserves management framework is strategic asset allocation with one year investment horizon. The responsibility is taken by Governing Board. Guideline: long term asset allocation and monetary policy restrictions. The main tasks of strategic asset allocation are valuation based deviations from long term asset allocation and benchmarks. After strategic asset allocation tactical decisions should be taken. Tactical asset allocation has investment horizon of three months. Responsibility is taken by Investment Committee. The guideline: strategic asset allocation, guidelines and limits. The main tasks in this level are tactical allocations and benchmarks. And finally at the lowest level practical portfolio management decisions should be taken. Portfolio management can be internal or external. At this stage portfolio managers take the responsibility for thier decisions. The main tasks of porfolio managers are to implement tactical asset allocation decisions and generate „Alpha“.

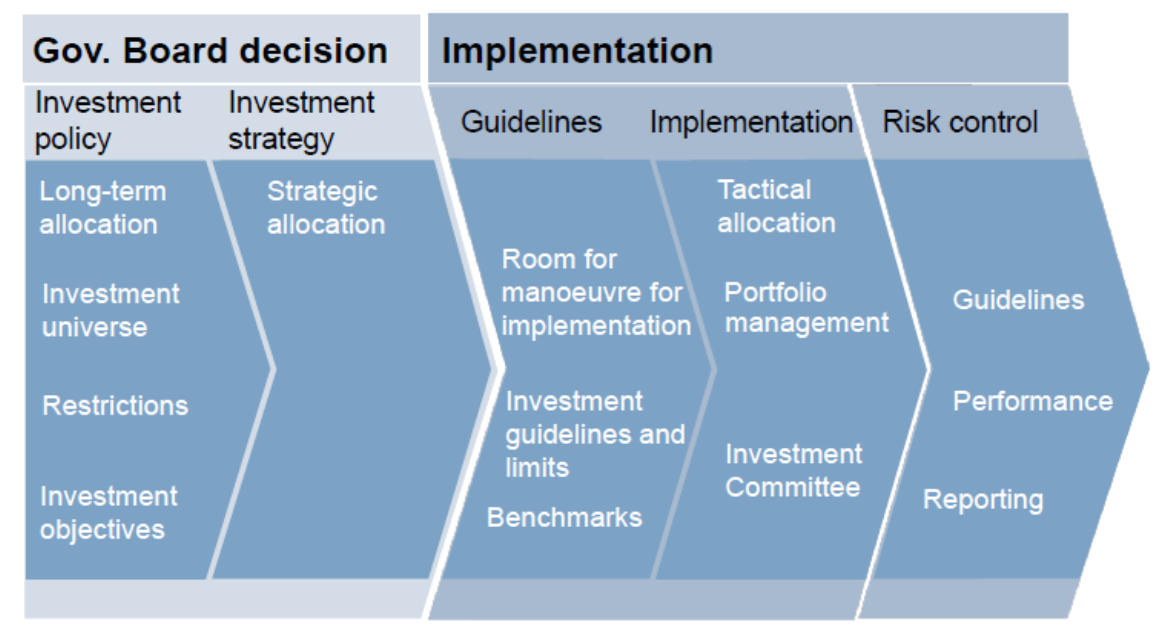

Fig. 5 Gov. Board decision and implementation Source: Swiss National Bank 
In figure 5 we see that a lot of attention before analysing central bank results should be paid to long-term and strategic allocation. So it is very important to look at central bank asset classes which are able to include into a foreign reserves portfolio.

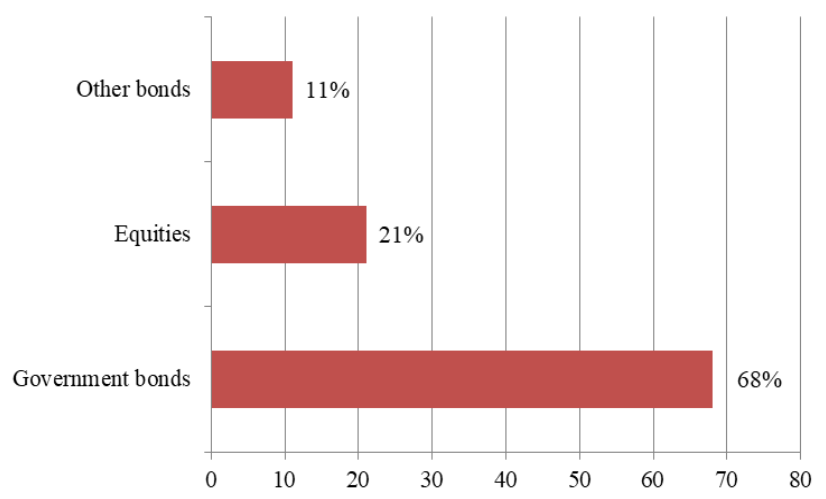

Fig. 6 Foreign exchange reserves: asset classes, in percents Source: Done by author using Swiss National bank data

In the Swiss National Bank's foreign exchange reserves structure we can see a significant part of equities. Comparing with other central banks it is quite modern foreign reserves management profile. But at the same time we should remember that Swiss National Bank has private shareholders which are interested in performance results and stock price volatility.

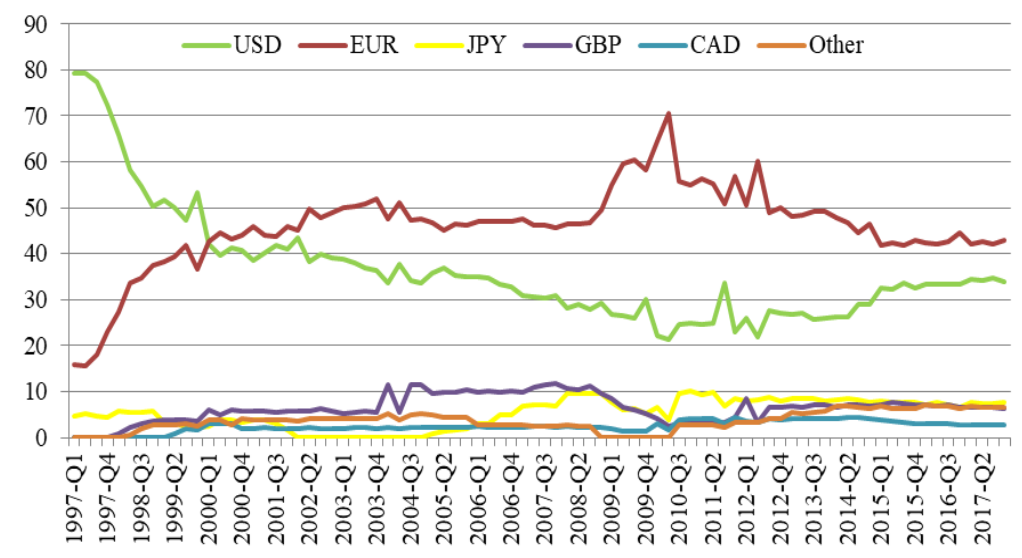

Fig. 7 Currency structure of Swiss foreign reserves, in percents

SNB foreign reserves are not only well diversified by different asset classes but also have diversified currency structure (fig. 7). This time portfolio size can also be a good factor as Switzerland takes the third place by foreign reserves amount.

According to central bank's performance measurement framework now it is important to look at the tendencies in financial markets. Before that we should have in mind the fact that Switzerland's central bank increased allocation to equities. The other important thing is that the SNB is the world's eighth biggest public investor. 


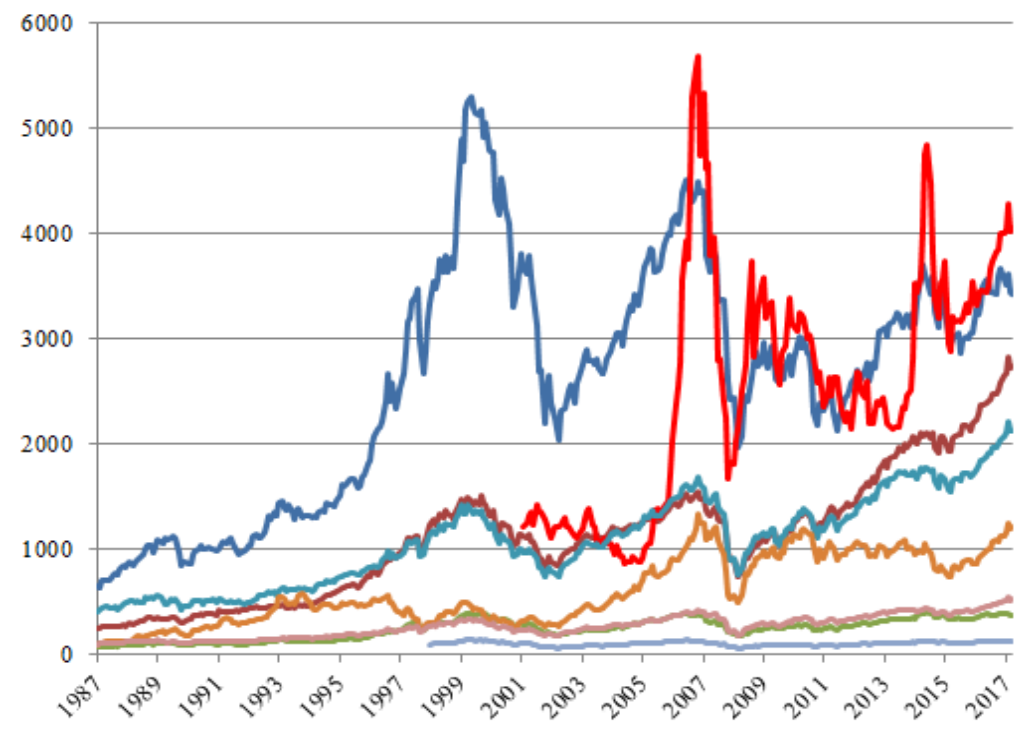

Fig. 8 Tendencies in stock market Source: Bloomberg

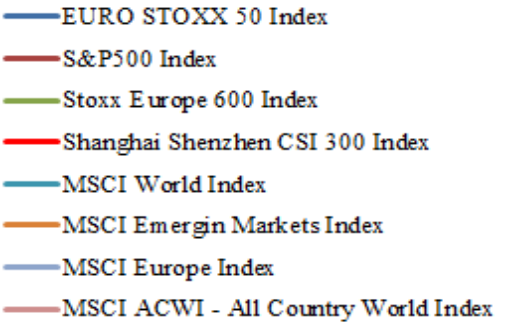

Stock markets' indices in 2017 increased all over the world. So SNB had very good performance results because of positive stock market effect. Increasing equity share in economic growth cycle SNB achieved impressive financial results.

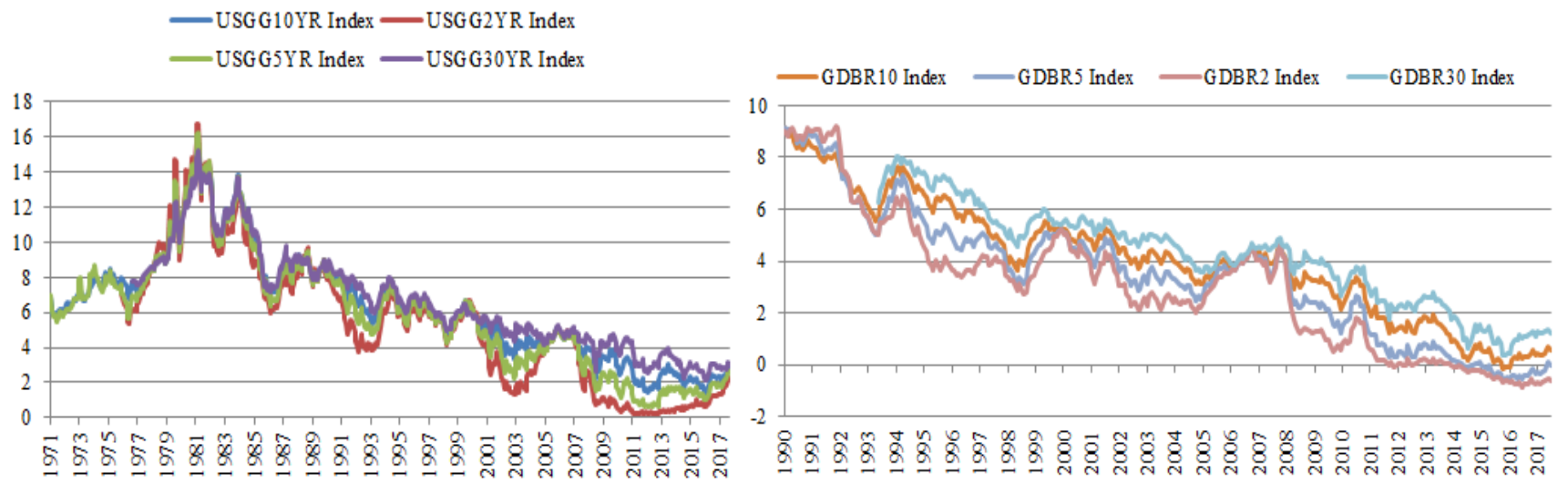

Fig. 9 US and Germany government bond yields' dynamic

Bond yields are still low but step by step increasing because of changing monetary policy. In 2017 bond yields had a tendency to increase so it has an impact on lower portfolio market value.

In table 2 we can see SNB investment performance results from 1999 to 2016 . Very important factor which is very obvious is currency risk. 
Table 2 SNB investment performance

\begin{tabular}{|c|c|c|c|c|c|c|}
\hline \multicolumn{7}{|c|}{ Investment performance } \\
\hline & \multicolumn{5}{|c|}{ Currency reserves } & \multirow{3}{*}{$\begin{array}{c}\text { Swiss } \\
\text { franc bonds } \\
\text { Total in CHF }\end{array}$} \\
\hline & Total in $\mathrm{CHF}$ & Gold in $\mathrm{CHF}$ & \multicolumn{3}{|c|}{ Foreign exchange reserves } & \\
\hline $\begin{array}{l}\text { Return on } \\
\text { investments (1) }\end{array}$ & & & Total in $\mathrm{CHF}$ & Currency return & Local return & \\
\hline 1999 & & & $9.7 \%$ & $9.2 \%$ & $0.4 \%$ & $0.7 \%$ \\
\hline 2000 & $3.3 \%$ & $-3.1 \%$ & $5.8 \%$ & $-2.0 \%$ & $8.0 \%$ & $3.3 \%$ \\
\hline 2001 & $5.2 \%$ & $5.3 \%$ & $5.2 \%$ & $-1.2 \%$ & $6.4 \%$ & $4.3 \%$ \\
\hline 2002 & $1.4 \%$ & $3.4 \%$ & $0.5 \%$ & $-9.1 \%$ & $10.5 \%$ & $10.0 \%$ \\
\hline 2003 & $5.0 \%$ & $9.1 \%$ & $3.0 \%$ & $-0.4 \%$ & $3.4 \%$ & $1.4 \%$ \\
\hline 2004 & $0.5 \%$ & $-3.1 \%$ & $2.3 \%$ & $-3.2 \%$ & $5.7 \%$ & $3.8 \%$ \\
\hline 2005 & $18.9 \%$ & $35.0 \%$ & $10.8 \%$ & $5.2 \%$ & $5.5 \%$ & $3.1 \%$ \\
\hline 2006 & $6.9 \%$ & $15.0 \%$ & $1.9 \%$ & $-1.1 \%$ & $3.0 \%$ & $0.0 \%$ \\
\hline 2007 & $10.1 \%$ & $21.6 \%$ & $3.0 \%$ & $-1.3 \%$ & $4.4 \%$ & $-0.1 \%$ \\
\hline 2008 & $-6.0 \%$ & $2.2 \%$ & $-8.7 \%$ & $-8.9 \%$ & $0.3 \%$ & $5.4 \%$ \\
\hline 2009 & $11.0 \%$ & $23.8 \%$ & $4.7 \%$ & $0.4 \%$ & $4.4 \%$ & $4.3 \%$ \\
\hline 2010 & $-5.4 \%$ & $15.3 \%$ & $-10.1 \%$ & $-13.4 \%$ & $3.8 \%$ & $3.7 \%$ \\
\hline 2011 & $4.9 \%$ & $12.3 \%$ & $3.1 \%$ & $-0.8 \%$ & $4.0 \%$ & $5.6 \%$ \\
\hline 2012 & $2.3 \%$ & $2.8 \%$ & $2.2 \%$ & $-2.3 \%$ & $4.7 \%$ & $3.7 \%$ \\
\hline 2013 & $-2.5 \%$ & $-30.0 \%$ & $0.7 \%$ & $-2.4 \%$ & $3.2 \%$ & $-2.2 \%$ \\
\hline 2014 & $8.0 \%$ & $11.4 \%$ & $7.8 \%$ & $2.6 \%$ & $5.1 \%$ & $7.9 \%$ \\
\hline 2015 & $-4.7 \%$ & $-10.5 \%$ & $-4.4 \%$ & $-5.6 \%$ & $1.3 \%$ & $2.3 \%$ \\
\hline 2016 & $3.8 \%$ & $11.1 \%$ & $3.3 \%$ & $-0.4 \%$ & $3.7 \%$ & $1.3 \%$ \\
\hline 2017 & $7.2 \%$ & $7.9 \%$ & $7.2 \%$ & $2.9 \%$ & $4.2 \%$ & $-0.1 \%$ \\
\hline
\end{tabular}

Source: Swiss National Bank

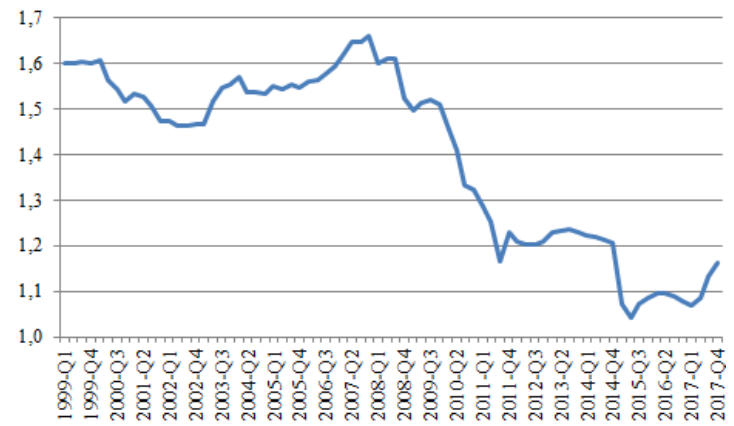

Fig. $10 \mathrm{CHF} / \mathrm{EUR}$

Source: Bloomberg 
The International Journal

ENTREPRENEURSHIP AND SUSTAINABILITY ISSUES

ISSN 2345-0282 (online) http://jssidoi.org/jesi/

2018 Volume 6 Number 1 (September)

http://doi.org/10.9770/jesi.2018.6.1(12)

In 2017 a drop in the franc against the euro helped to achieve better investment results and generate impressive net profit for the year.

Table 3. SNB stock price information

\begin{tabular}{|l|r|r|r|r|r|}
\hline In Millions of CHF except Per Share & FY 2014 & FY 2015 & FY 2016 & FY 2017 & Current \\
\hline Last Price & 1060,00 & 1099,00 & 1750,00 & 3889,00 & 5660,00 \\
\hline Period-over-Period \% Change & 1,44 & 3,68 & 59,24 & 122,23 & \\
\hline Open Price & 1065,00 & 1069,00 & 1095,00 & 1780,00 & 5700,00 \\
\hline High Price & 1150,00 & 1400,00 & 2120,00 & 4724,00 & 5760,00 \\
\hline Low Price & 991,00 & 980,00 & 1028,00 & 1615,00 & 5600,00 \\
\hline Market Capitalization & 106,0 & 109,9 & 175,0 & - & 566,0 \\
\hline Current Shares Outstanding & 0,10 & 0,10 & 0,10 & 0,10 & 0,10 \\
\hline Equity Float & 0,08 & 0,08 & 0,08 & 0,08 & 0,08 \\
\hline
\end{tabular}

Source: Done by author using Bloomberg data

Table 4. SNB financial results

\begin{tabular}{|c|c|c|c|c|c|}
\hline In Millions of CHF except Per Share & FY 2013 & FY 2014 & FY 2015 & FY 2016 & FY 2017 \\
\hline Interest Income - Investments & $-15302,6$ & 4344,0 & $-2917,9$ & 5501,2 & - \\
\hline Net Interest Income & - & - & $-2917,9$ & - & - \\
\hline Trading Gains (Losses) & 3131,6 & 34487,7 & $-19943,0$ & 19365,8 & - \\
\hline Other Gains (Losses) & 3426,3 & 12,1 & 11,6 & 13,6 & - \\
\hline Salaries Wages and Employee Benefits & 172,6 & 150,2 & 157,7 & 160,6 & - \\
\hline Depreciation Expense & 39,0 & 37,6 & 39,0 & 38,8 & - \\
\hline Other Operating Expenses & 25,5 & 233,6 & 86,9 & 74,2 & - \\
\hline General and Administrative Expenses & 96,9 & 109,6 & 117,6 & 130,6 & - \\
\hline Operating Income & - & 38312,9 & $-23250,6$ & 24476,4 & - \\
\hline $\begin{array}{r}\text { Equity In Earnings of Affiliate/Joint } \\
\text { Ventures }\end{array}$ & $-2,1$ & - & - & - & - \\
\hline Income Before Income Taxes & $-9076,6$ & 38312,9 & $-23250,6$ & 24476,4 & - \\
\hline Total Cash Common Dividends & 0,0 & 1,5 & 1,5 & 1,5 & - \\
\hline Weighted Avg. Shares - Basic \& Diluted & - & - & - & - & 0,1 \\
\hline Net Income & $-9076,6$ & 38312,9 & $-23250,6$ & 24476,4 & 54371,6 \\
\hline Salaries Wages and Employee Benefits & 172,6 & 150,2 & 157,7 & 160,6 & - \\
\hline Depreciation Expense & 39,0 & 37,6 & 39,0 & 38,8 & - \\
\hline Equity In Earnings of Affil/Joint Ventures & $-2,1$ & - & - & - & - \\
\hline Pension Expense (Income) & 44,3 & 16,2 & 19,1 & 19,3 & - \\
\hline Weighted Avg. Shares - Basic \& Diluted & 0,1 & 0,1 & 0,1 & 0,1 & - \\
\hline Trading Gains (Losses) & 3131,5 & 34487,8 & $-19943,0$ & 19365,9 & 一 \\
\hline Other Gains (Losses) & 3426,4 & 12,2 & 11,6 & 13,4 & - \\
\hline Interest Income - Investments & $-15374,5$ & 4278,0 & $-2982,2$ & 3918,7 & - \\
\hline Interest Expense - Other & 7,5 & 8,9 & 2,3 & $-1522,0$ & — \\
\hline Total Interest Income & 79,4 & 74,8 & 66,5 & 60,6 & - \\
\hline
\end{tabular}




\begin{tabular}{|r|r|r|r|r|r|}
\hline Employer Contribution (Pension) & - & 18,1 & 19,1 & 19,3 & - \\
\hline Auditors Remuneration For Audit & 0,4 & 0,3 & 0,3 & 0,3 & - \\
\hline Other Employee Costs & 39,3 & 6,9 & 7,6 & 9,1 & - \\
\hline Wages And Salaries & 111,1 & 116,7 & 122,2 & 123,2 & - \\
\hline Social Security Costs & 22,3 & 26,6 & 27,9 & 28,3 \\
\hline
\end{tabular}

After analysing SNB foreign reserves management framework and central bank's results the conclusion could be made that in this case we had very modern and with big risk tolerance top level decisions and very positive movements of assets prices and currency risk effect. SNB can not be compared to other central banks because of it size, risk tolerance and local currency movements. The main thing which can be taken is openness of SNB. Of course this is because of private investors but this practice of openness could be implemented and in other central banks also.

\section{Conclusions}

This paper presents the main issues in central banks' performance valuation. Usually central banks face political and public pressure when they get loss and usually politicians like to compare and value different banks results. But the problem is that we cannot just take net profit of various central banks and value if its performance is good or bad. The first point we should look at is the structure of strategic asset allocation. Board decisions and risk profile is the most important aspects in central bank performance measurement. Even knowing this factor it is very difficult to compare central banks results because after research of a lot of central banks' public information, the conclusion can be made that central banks do not disclose their investment policy in great details. Especially in most cases when they do not have private shareholders.

The other aspect that should be taken into consideration is the size of foreign reserves portfolio. After analysing different central banks results the conclusion can be made that the size of portfolio matters but it is not the main factor.

And finally the other factor, which should be included in performance valuation, is tendencies in financial markets. It is very important to value the tendencies of different asset classes which are in foreign reserves portfolio and the other aspect is to pay attention to its size comparing with other asset classes. And at the end of analysis we have to value the effect of currency risk exposure as sometimes it can be one of the main factor explaining central bank's results.

Central banks' performance valuation issues are interesting topic which should be analyzed in more details as central banks play a very important role in economy. After this research we can make an assumption that central banks will improve their public communication and will explain their performance in more details, especially about foreign reserves management.

For further research it would be interesting to create central banks performance measurement ranking system in order in a right way to compare different central banks' results. 
The International Journal

ENTREPRENEURSHIP AND SUSTAINABILITY ISSUES

ISSN 2345-0282 (online) http://jssidoi.org/jesi/

2018 Volume 6 Number 1 (September)

http://doi.org/10.9770/jesi.2018.6.1(12)

\section{References}

Archer, David; Moser-Boehm, Paul. 2013. Central bank finances. BIS papers No 71 . Retrieved from: https://www.bis.org/publ/bppdf/bispap71.pdf

Bloomberg terminal data

Bunea, Daniela; Karakitsos, Polychronis; Merriman, Niall; Studener, Werner. 2016. Profit distribution and loss coverage rules for central banks. Occasional Paper $\quad$ Series $\quad$ No169. from: https://www.ecb.europa.eu/pub/pdf/scpops/ecbop169.en.pdf?f7073b79c2f6f62c79918dc24088dd00

Central bank and monetary authority websites. Retrieved from: https://www.bis.org/cbanks.htm

Fisher J., Stephen. Asset allocation for Central Banks. First degree global asset management. Research paper. Retrieved from: http://www.firstdegree.asia/assets/asset-allocation-for-central-banks.pdf

Goncharov, Igor; Ioannidou, Vasso; Schmalz, Martin. 2017. (Why) do central banks care about their profits? Available at SSRN: https://ssrn.com/abstract=2979887 or http://dx.doi.org/10.2139/ssrn.2979887

Investment Policy Guidelines of the Swiss National Bank (SNB). $2015 . \quad$ Retrieved from: https://www.snb.ch/en/mmr/reference/snb legal richtlinien/source/snb legal richtlinien.en.pdf

Maechler, M. Andrea. 2016. Investment policy in times of high foreign exchange reserves. Money Market Event. Swiss National Bank, Zurich.

Mminele, Daniel. 2013. Establishing a proper governance framework for central bank reserves management. BIS central bankers' speeches. Retrieved from: https://www.bis.org/review/r130312h.pdf

Nugee, John. 2001. Foreign exchange reserves management. Centre for Central Banking Studies. London: Published by Bank of England.

Nugee, John. 2015. Current issues in central bank reserves management. Hong Kong Monetary Authority. Proceedings of OeNB Workshops No. 20.

Schroders. 2016. Equities in reserve portfolios. For professional investors and advisers only.

Smith, Gary; Nugee, John. 2015. The changing role of central bank foreign exchange reserves. Official Monetary and Financial Institutions Forum.

Vinals, Jose. 2013. Prepared by the Monetary and Capital Markets Department. International Monetary Fund. Revised Guidelines for Foreign Exchange Reserve Management. Retrieved from: https://www.imf.org/external/np/pp/eng/2013/020113.pdf

World Bank, Reserves Advisory and Management Program, Market Risk, Indexation of Treasury Securities and Performance Measurement, January 22-26, 2018 | Paris, France 
Deimante TERESIENE is Associated Professor at Vilnius University. Her research interests are: Monetary policy, Financial markets, Ethics in finance, Corporate finance, Banking, Portfolio construction and management.

ORCID ID: orcid.org/0000-0002-8107-1964

Register for an ORCID ID:

https://orcid.org/register

Copyright (C) 2018 by author(s) and VsI Entrepreneurship and Sustainability Center

This work is licensed under the Creative Commons Attribution International License (CC BY).

http://creativecommons.org/licenses/by/4.0/

cc) (†) Open Access 